
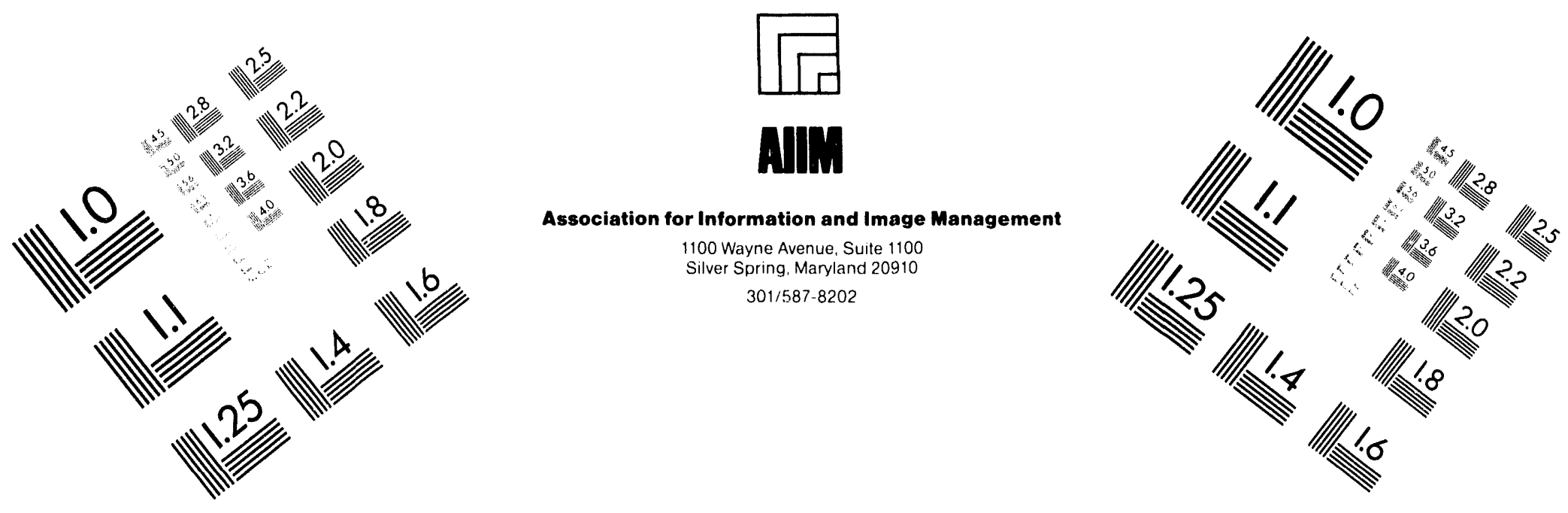

\title{
Centimeter
}

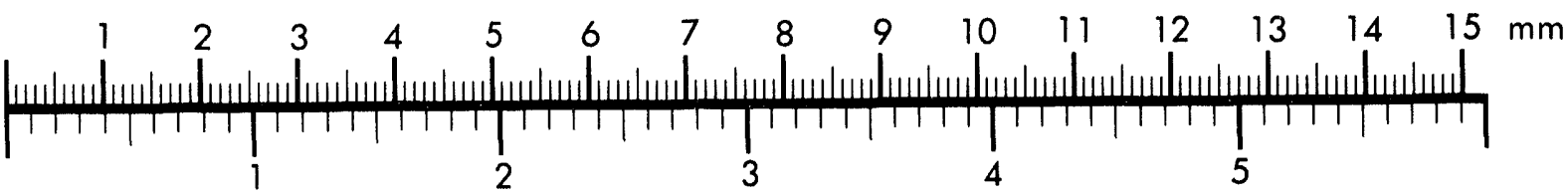

Inches
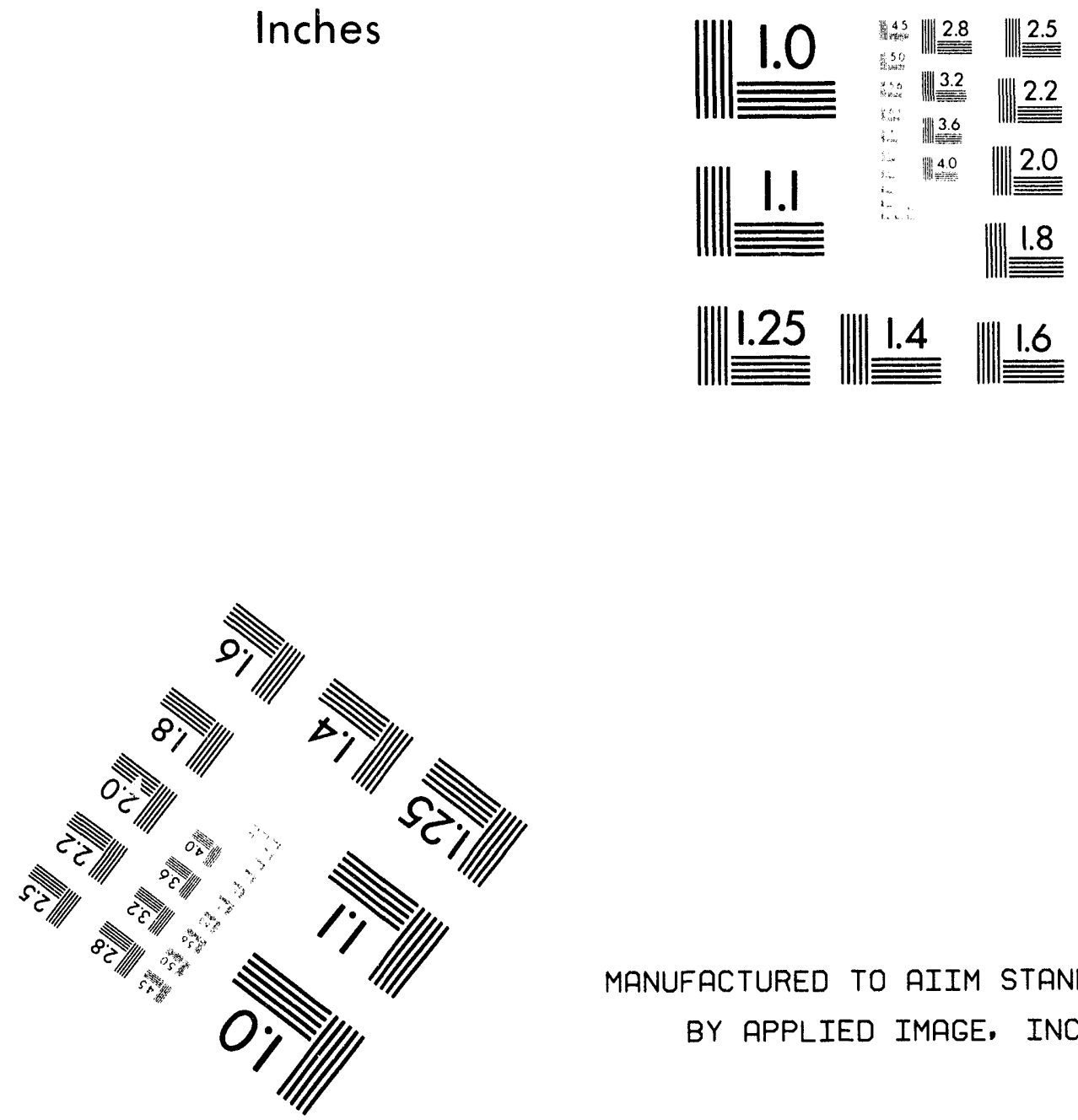

MANUFACTURED TO AIIM STANDARDS

BY APPLIED IMAGE, INC.

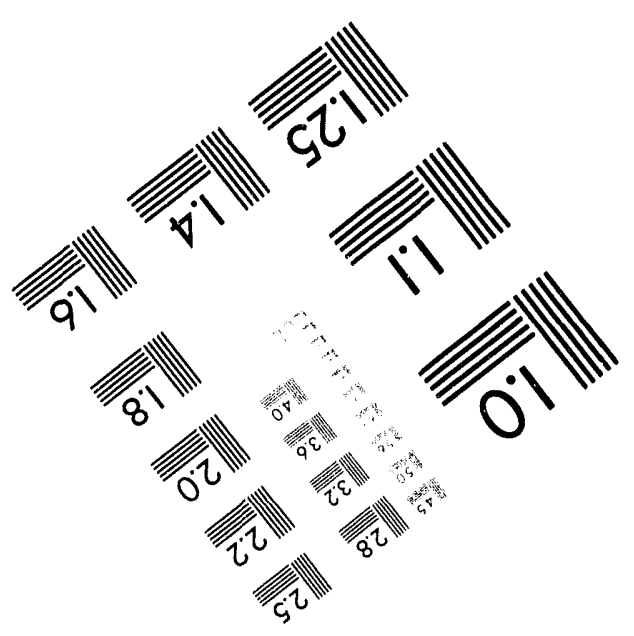



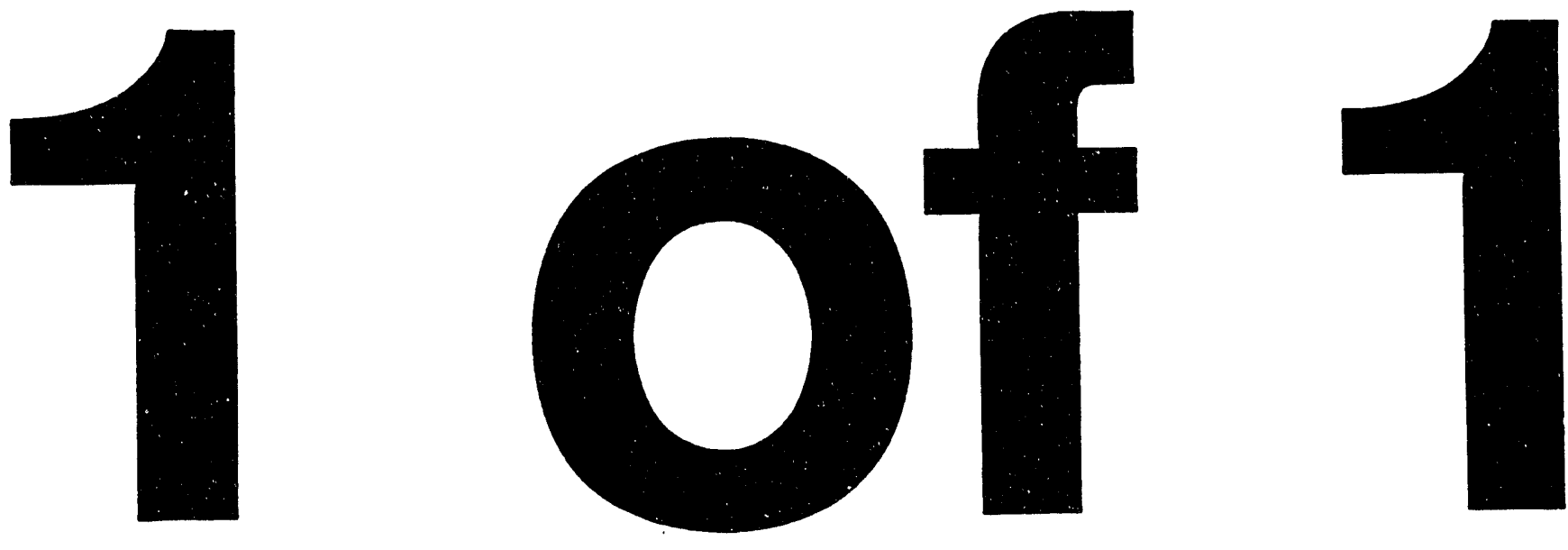


\section{CURRENT VEGETATION CHARACTERISTICS WITHIN TREE-KILL ZONES OF F- AND H-AREAS (U)}

by

Nelson, E. A.

Westinghouse Savannah River Company

Savannah River Site

Aiken, South Carolina 29808

Irwin, J.E.

DOE Contract No. DE-AC09-89SR18035

This paper was prepared in connection with work done under the above contract number with the U.S.

Department of Energy. By acceptance of this paper, the publisher and/or recipient acknowledges the U.S.

Government's rigint to retain a nonexclusive, royalty-free license in and to any copyright covering this paper, along with the right to reproduce and to authorize others to reproduce all or part of the copyrighted paper. 


\section{DISCLAIMER}

This report was prepared as an account of work sponsored by an agency of the United States Governmen: Neither the United States Government nor any agency thereof, nor any of their employees, makes any warranty, express or implied, or assumes any legal liability or responsibility for the accuracy, completeness, or usefulness of any information, apparatus, product, or process disclosed, or represents that its use would not infringe privately owned rights. Reference herein to any specific commercial product, process, or service by trade name, trademark. manufacturer, or otherwise does not necessarily constitute or imply its endorsement, recommendation, or favoring by the United States Government or any agency thereof. The views and opinions of authors expressed herein do not necessarily state or reflect those of the United. States Government or any agency thereof.

This report has been reproduced directly from the best available copy.

Available to DOE and DOE contractors from the Office of Scientific and Technical Information. P. O. Box 62. Oak Ridge. TN 37831: prices available from (615) $576-8401$.

Available to the public from the National Technical Information Service, U. S. Department of Commerce, 5285 Port Royal Rd., Springfield, VA 22161 
WSRC-TR-94- 0233

D. B. Moore-Shedrow, Manager

Authorized Derivative Classifier

\section{CURRENT VEGETATION CHARACTERISTICS WITHIN TREE-KILL ZONES OF F- AND H-AREAS (U)}

Eric A. Nelson, Environmental Sciences Section

Julie E. Irwin, Environmental Sciences Section

Approved by: Danfone - Jzedsas

D. B. Moore-Shedrow, Section Manager

Environmental Sciences Section

Publication date: April 1994

Westinghouse Savannah River Company

Savannah River Technology Center

Aiken, South Carolina 29808 
Current Vegetation Characteristics Within Tree-Kill Zones of F-and H-Areas (U)

by

Eric A. Nelson and Julie E. Irwin

\section{INTRODUCTION}

Vegetation of two wetland areas previously adversely affected by outcropping groundwater was characterized to evaluate the type and extent of revegetation. When the damage first became evident in the late 1970's and early 1980's the areas were examined and described to try to establish the cause of the extensive tree mortality (Loehle and Gladden, 1988; Mackey, 1988; Haselow et al., 1990; LeBlanc and Loehle, 1990; Greenwood et al., 1990). The F-and H-Area seepage basins above the wetland areas received waste products from the separation areas beginning in 1955 . The operation, estimated loading, and current status of the basins were summarized by Killian et al. (1987a, 1987b). Analysis of soil and water at the affected seeplines where the tree-kill was occurring confirmed that the surface water was strongly influenced by constituents of the F- and H-Area seepage basins (Looney et al., 1988). While no single cause of the forest mortality was defined, alterations in the hydrology and siltation patterns, $\mathrm{pH}$ changes, increased conductivity, and increased levels of sodium, nitrogen compounds, and aluminum, were believed to be interacting to cause the mortality.

The results of subsequent sampling (Dixon and Rogers, 1993) have shown that the contamination at the seeplines from the basins has begun to subside as the plume moves into the wetlands and down gradient towards Fourmile Branch. This vegetation evaluation was undertaken to assess the recovery, if any, that has taken place since the initial damage. 


\section{STUDY AREAS AND METHODS}

The two areas examined in 1993 were the most severely affected ones in F- and $\mathrm{H}$ Areas (Figure 1). These areas are among those previously described and sampled in the 1980's. Prior to damage the sites were pure swamp tupelo (Nyssa sylvatica var. biflora) stands. All mature individuals were killed by the stress that occurred in the wetland areas. No overstory, other than a few widely scattered individuals, remained in either location.

A series of vegetation characterization plots was installed to quantify the recovery. These plots were circular milacre plots (43.56 sq. ft/plot, $4.05 \mathrm{sq} . \mathrm{m} / \mathrm{plot}$ ) installed at uniform intervals along transects in the two areas. The F-Area sampling was done along four transects that crossed the area (Figure 2) and the H-Area sampling was along a single transect through the center of the area extending the length of the tree-kill area (Figure 3). The transects were placed to best characterize the variation present in the areas based on preliminary visual assessments.

Forty plots were installed in the F-Area location and 56 plots were installed in the $\mathrm{H}$ Area location. Within each plot, all individuals were identified to species, where possible. Taxonomic nomenclature followed Radford et al. (1968). Sampling took place in August and September 1993. For each plot the height of the tree and shrub seedlings, the number of stems of the vines, and the percent cover of the herbs were recorded on data sheets. Unless otherwise indicated, the terms "tree" and "shrub" throughout this report refer to tree and shrub seedlings, generally only one or two years old and quite small. Plot data were summarized to indicate qualitative and quantitative 
information about the current status of the two tree-kill areas sampled. The two sampling areas were considerably different and will be discussed separately.

\section{F-AREA LOCATION}

The substrate within the F-Area tree-kill area consists of thick, flocculent, deep, muck with water flowing through it and algae growing on top of it. Vegetation within the FArea tree-kill area is sparse. The canopy has been almost totally destroyed; only a few live trees remain. Some standing dead trunks and many fallen trunks are scattered throughout the area. Most of the existing understory vegetation is growing in widely scattered clumps on stumps, fallen logs, and accumulated debris. An occasional herbaceous wetland plant was noted growing in the muck near the upland edge of the tree-kill area.

\section{F-AREA SAMPLING RESULTS}

Twenty six species were encountered in sampling (Table 1). Of the 40 plots sampled, seven $(17.5 \%)$ were totally devoid of vegetation. Transect 1, closest to the source of the groundwater discharge and farthest from the surrounding forest, contained the least number of species (11), 4 (36\%) of which were ground cover. Transect 1 also contained the least number of individuals in all strata (Table 2). Transects 2, 3 and 4 contained approximately the same number of species each (Table 2). Transect 4, which is closest to the adjacent forest and Fourmile Branch, contained the highest number of tree seedlings (69 individuals versus 22 or less in each of the other transects).

Canopy Stratum: Live canopy-height trees occurred in only two plots $(7.5 \%)$-one swamp tupelo (Nyssa sylvatica var. biflora) in each. Both live trees showed signs of 
stress including adventitious leaves tightly clustered on the trunks and a scarcity of limbs. No other species were present in the canopy. Two standing dead canopy-sized swamp tupelo individuals were also encountered in sampling.

Understory Stratum: All individuals in the understory stratum were growing on stumps, fallen logs, or clumps of debris. Tree seealings occurred in $65 \%$ of the plots and shrub seedlings occurred in $20 \%$. Tree seedlings were more numerous than shrub seedlings (Fig 4). Seven species of tree seedlings and four species of shrub seedlings were encountered in sampling (Table 1). Data by plot for the tree and shrub seedlings and the vine stems are included in Table 3 and illustrated in Figure 5.

The most abundant tree seedlings were red maple (42\%) and pine (25\%). It is not surprising that red maple and pine were the most abundant species. Mature individuals of both species were present in the adjacent forest to provide a seed source; and the fruits of both (samaras) are wind dispersed. They are early successional species able to invade, germinate, and grow rapidly under disturbed habitat conditions of high light intensity and poor substrate.

Only $12.7 \%$ of the tree seedlings were swamp tupelo (Nyssa sylvatica var. biflora) which was probably the dominant canopy species prior to canopy destruction. The low numbers of swamp tupelo seedlings indicate that the former canopy dominant is not currently re-establishing in the impacted area. The swamp tupelo fruits (drupes), being heavy, are not wind dispersed. If they fall on soil, they tend to stay where they land. If they fall into water, they float with the current. Given the scattered nature of above-water substrate in the tree-kill area, the chances of a swamp tupelo drupe's landing on or floating onto a substrate suitable for germination are limited. Therefore, the low number of swamp tupelo seedlings is to be expected. 
That none of the shrubs is wind dispersed probably accounts for their low numbers. Virginia-willow (Itea virginica), a shrub normally found in swamps, wet woodlands, and along wooded streams, was the most abundant shrub seedling. It made up $40 \%$ of the shrub population but occurred in only $5 \%$ of the plots.

All tree and shrub seedlings were fairly small. Mean height of tree seedlings was 23.2 $\mathrm{cm}$. Mean height of shrub seedlings was $48.6 \mathrm{~cm}$. Only 2 rather chlorotic individuals were taller than $100 \mathrm{~cm}$-inkberry (llex glabra, a shrub) and sweet bay (Magnolia virginiana, a tree), at $110 \mathrm{~cm}$ each. All individuals showed evidence of stress: chlorotic leaves, stunted growth, and a lack of visible vigor normally associated with the seedling growth stage. The combination of poor substrate and the evidence of stress indicates that the current crop of seedlings is unlikely to survive to maturity to reforest the area.

Vines: Vines occurred in $25 \%$ of the plots sampled. Six species, including 3 species of greenbrier (Smilax), were encountered in sampling (Table 1). Most of them were seedlings and quite small. All were growing above the substrate on stumps, fallen logs, or debris.

Groundcover Stratum: Ground-cover species were widely distributed, but sparse. They occurred in $80 \%$ of the plots sampled, but covered only $7.29 \%$ of the area. Grasses accounted for $98.4 \%$ of the vegetation cover. Nine ground-cover species ( 4 forbs, 3 grasses, one fern, and one moss) were encountered in sampling (Table 1). At least one species of grass occurred in each plot that contained ground cover vegetation. Forbs occurred $10 \%$ of the plots. One individual (Peltandra virginica, a forb) was growing in the substrate; all others were growing above the substrate on stumps, fallen logs, or piles of debris. 


\section{H-AREA LOCATION}

Soil in the H-Area tree-kill zone was much more consolidated than the soil in the F-Area site. Much of the area had standing water at the surface. Depth increased as the plot number increased along the transect. Very few canopy trees were still alive. Some standing dead trees were evident and many logs were on the ground throughout the area.

\section{H-AREA SAMPLING RESULTS}

A total of 40 species were identified in the H-Area sampling location (Table 4). The affected area had two distinct characterizations. Plots 1 through 15 were less wet and showed evidence of revegetation by woody species. The plots were clearly impacted by the prior seep, but were recovering much faster than plots 16 through 56. Plots 16 through 56 were much wetter and dominated by cattails (Typha sp.) and cut grass (Leersia oryzoides).

Canopy Stratum: Only one live mature tree, a swamp tupelo (Nyssa sylvatica var. biflora), was encountered within the plots. Evidence of the former mature stand was present throughout the sampling area in the form of snags and logs.

Understory Stratum: Vegetation characteristic of this stratum occurred only in the first 15 plots (Table 5, Figure 6). The shrub species were much more numerous than were the tree species (128 individuals vs. 19 individuals). Of the tree seedlings encountered, red maple (Acer rubrum) was dominant (47.4\%), followed by pine (Pinus sp.) and swamp tupelo ( $21 \%$ each). The remainder consisted of one tulip tree (Liriodendron 
tulipifera) and one sweetgum (Liquidambar styraciflua). The shrub species were dominated by red bay (Persea borbonia) (62.5\%), followed by wax myrtle (Myrica cerifera) (14.1\%), blackberry (Rubus sp.) (10.9\%), and sea-myrtle (Baccharis halimifolia) $(7.8 \%)$. The remaining four species encountered made up the remaining $4.7 \%$.

The quantity and diversity of individuals encountered in the first 15 plots is indicative of the drier nature of this section which has allowed seeds to germinate and establish themselves on the soil. This tree-kill zone is narrow along the entire transect with ample seed sources on either side of it for seed production and dispersal. Many of the species present are early successional and would be the ones expected to recolonize disturbed areas.

In the first 15 plots, the general health of the shrub and tree seedlings was better than observed in the F-Area kill-zone. While all individuals of the tree species were small, averaging less than $30 \mathrm{~cm}$, they appeared healthy. Lack of size was probably attributable to their age, most being only 1 or 2 years old. The shrub species were generally large and vigorous. Many species averaged over one meter in height. The largest individuals encountered, especially the red bay and wax myrtle, were often over 3 meters tall.

Vines: Species categorized as vines were identified in nearly half of the plots $(48 \%)$ in the $\mathrm{H}$-Area kill zone. They occurred in the first 15 plots alorig with the shrub and tree seedling component. The remaining plots that contained vines typically had a large log through them. This provided an elevated surface and localized disturbance of the cattail and cut grass component of the plots (e.g. plots 41-43) and allowed vines to establish. 
Smilax sp. and Mikania scandens were the most common vine species encountered and made up $75 \%$ of the stems counted.

Groundcover Stratum: Herbaceous species occurred in all plots in the H-Area sampling. A total of 20 species of forbs, grasses and ferns were identified (Table 4). The average number of species occurring within the plot was greater for plots 1 through 15 (8.0 per plot) than for the remaining plots (4.4 per plot). Many of the herbaceous species occurred only in the first 15 plots (Table 6). Beginning with plot 16, Leersia and Typha began to dominate the plots. This plot was the point at which the water became slightly deeper and the soil slightly less consolidated. Leersia was more dominant than Typha on the exterior two or three plots $(16,17$ and 52, 53, 54). These plots were probably a transition between the different hydrological environments. Plots 18 through 51 were dominated by Typha with a smaller component of Leersia (Figure 7). Reduced percent cover (such as in plot 43) was due to log debris in the plot.

\section{COMPARISON WITH ADJACENT FOREST}

The sparse vegetation of the $\mathrm{F}$ - and $\mathrm{H}$-Area tree-kill areas is in stark contrast to the adjacent forest. The species composition is similar, but the structure is very different. The tree-kill areas are not stratified as a relatively undisturbed forest would be. The species normally associated with canopy, subcanopy, and shrub layer are present in the F-Area, but as sickly seedlings perched above the substrate on stumps, logs, and piles of debris. None of the current species are capable of surviving continuous deep flooding that is typical of these areas. Therefore, without the stumps, logs, and debris the vegetation could not exist. The adjacent forest, however, is characterized by a closed canopy of mature mixed hardwoods and loblolly pines (Pinus taeda). The 
subcanopy and shrub layers are intact and well defined; and the plants are growing on a consolidated soil more characteristic of these wetland areas.

The composition of the first 15 plots of the H-Area tree-kill area indicates that this section is beginning to re-establish itself as a bottomland hardwood forest. Many years will be needed to allow the canopy to form and begin to layer itself into a selfperpetuating forest. The hydrology of the remainder of the H-Area tree-kill area and the lack of tree and shrub individuals indicate that this area is not currently suitable for natural regeneration of the bottomland hardwood forest.

\section{SUMMARY}

This vegetation characterization of the F-and $\mathrm{H}$-Area tree-kill zones is the first description of the recovery of these areas. With the exception of a small portion of the $\mathrm{H}$-Area location, very little recovery has occurred. Indications are that the areas are not returning to their prior condition. Vegetation in the F-Area still shows signs of continuing stress. Vegetation in most of the H-Area is herbaceous and of the persistent emergent classification. This may be a successional stage which will later lead to a woody plant community, but the duration of this phase is unknown. An effort to quantify the current soil and water characteristics may be able to define some of the lingering problems of vegetation invasion into these wetland areas.

\section{REFERENCES}

Dixon, K.L. and V.R. Rogers. 1993. Results of the second quarter tritium surveys of the F- and H-Area seeplines: September 1992. WSRC-TR-93-129, Westinghouse Savannah River Co., Aiken, SC 29808. 
Greenwood, K.P., M.E. Hane, A.J. Lander, C. Loehle, and C.J. Richardson. 1990. Assessment of tree toxicity neat the $\mathrm{F}$ - and $\mathrm{H}$-Area seepage basins of the Savannah River Site (U). WSRC-TR-90-253, Westinghouse Savannah River Co., Aiken, SC 29808.

Haselow, J.S., M. Harris, B.B. Looney, N.V. Halverson, and J.B. Gladden. 1990. Analysis of soil and water at the Four Mile Creek seepline near the F \& $H$ Areas of SRS (U). WSRC-RP-90-0591, Westinghouse Savannah River Co.,SRL, Aiken, SC 29808.

Killian, T.H., N.L. Kolb, P. Corbo, and I.W. Marine. 1987a. Environmental Information Document: F-Area seepage basins. DPST-85-704, E.I. duPont de Nemours \& Co., SRL, Aiken, SC 29808.

Killian, T.H., N.L. Kolb, P. Corbo, and I.W. Marine. 1987b. Environmental Information Document: H-Area seepage basins. DPST-85-706, E.I. duPont de Nemours \& Co., SRL, Aiken, SC 29808.

LeBlanc, D.C. and C. Loehle. 1990. The effect of contaminated groundwater on tree growth: a tree-ring analysis (U). WSRC-RP-90-552, Westinghouse Savannah River Co., Aiken, SC 29808.

Loehle, C. and J. Gladden. 1988. Preliminary assessment of tree mortality near F- and H-Area seepage basins. DPST-88-260, E.I. duPont de Nemours \& Co., SRL, Aiken, SC 29808.

Looney, B.B., J.E. Cantrell and J.R. Cook. 1988. Sampling and analysis of surface water in the vacinity of the F-and H-Area seepage basins. DPST-88-229, E.I. duPont de Nemours \& Co., SRL, Aiken, SC 29808.

Mackey, H.E. Jr. 1988. Initial evaluation of photographic data of F-and H-Area seepage basin outcrops. DPST-88-314, E.I. duPont de Nemours \& Co., SRL, Aiken, SC 29808. 
Radford, A.E., H.E. Ahles, and C.R. Bell. 1968. Manual of the Vascular Flora of the Carolinas. Univ. of North Carolina Press, Chapel Hill, NC. 
Table 1. F-Area tree-kill area plant species by strata, August 1993.

TREE STRATUM

Mature Trees

Nyssa sylvatica var. biflora

\section{SEEDLING STRATUM}

Tree Seedlings

Acer rubrum

llex opaca

Liquidambar styraciflua

Liriodendron tulipifera

Magnolia virginiana

Nyssa sylvatica var. biflora

Pinus sp.

Shrub Seedlings

llex glabra

Itea virginica

Myrica cerifera

Rubus sp.

\section{VINE STRATUM}

Gelsimium sempervirens

Parthenocissus quinquefolia

Smilax laurifolia

Smilax glauca

Smilax walteri

Vitis rotundifolia

\section{GROUNDCOVER STRATUM}

Forbs

Boehmeria cylindrica

Eupatorium capillifolium

Peltandra virginica

Hypericum walteri

Grasses

Andropogon virginicus

Arundinaria gigantea

Unknown grass

Ferns

Woodwardia areolata

Moss

Sphagnum sp. swamp tupelo

red maple

American holly

sweetgum

tulip tree

sweet bay

swamp tupelo

pine

ink-berry

Virginia-willow

wax myrtle

blackberry

yellow Jessamine

Virginia creeper

laurel-leaf greenbrier

cat-brier

coral greenbrier

muscadine

false nettle

dog-fennel

arrow arum

St. Johns wort

broomsedge

giant cane

netted chain fern

sphagnum 
Table 2. Number of plant species and number of tree, shrub, and vine individuals in each transect of F-Area.

\begin{tabular}{lrrrrr} 
& Trtinsect & Transect & Transect & Transect & TOTAL \\
\cline { 2 - 6 } & 1 & 2 & 3 & 4 & \\
Total \# species & 11 & 16 & 14 & 15 & 26 \\
\# Tree seedlings & 16 & 19 & 22 & 69 & 126 \\
\# Shrub seedlings & 1 & 6 & 9 & 6 & 22 \\
\# Vine stems & 4 & 7 & 7 & 9 & 27
\end{tabular}


Table 3. Number of tree seedlings, shrub seedlings, and vines per plot in each transect of F-Area.

$\begin{array}{ccc}\text { Tree } & \text { Shrub } & \\ \text { PLOT\# Seedlings } & \text { Seedlings }\end{array}$

TRANSECT 1

2

3

4

5

6

7

8

$10 \quad 1$

113

TRANSECT 2

$\begin{array}{llll}1 & 5 & 5 & 5 \\ 2 & & & 1 \\ 3 & 1 & & \\ 4 & 6 & & \\ 5 & 5 & & \\ 6 & 1 & & \\ 7 & & & 1 \\ 8 & & 1 & \end{array}$

TRANSECT 3

$\begin{array}{cccc}1 & 7 & 3 & 4 \\ 2 & 3 & 6 & \\ 3 & 2 & & \\ 4 & 4 & & \\ 5 & & & \\ 6 & & & 3 \\ 7 & & & \\ 8 & 3 & & \\ 9 & & & \\ 10 & 3 & \end{array}$

TRANSECT 4

\begin{tabular}{cccc}
1 & 2 & & 1 \\
2 & 13 & 1 & 2 \\
3 & 23 & & 4 \\
4 & 4 & 4 & \\
5 & 2 & & \\
6 & 3 & & \\
7 & 9 & 1 & \\
8 & 6 & & 2 \\
9 & 1 & & \\
10 & 6 & & \\
\hline
\end{tabular}


Table 4 H-Area tree-kill area plant species by strata, September 1993.

\section{TREE STRATUM}

Mature Trees

Nyssa sylvatica var. biflora

swamp tupelo

\section{SEEDLING GTRATUM}

Tree Seedlings

Acer rubrum

llex opaca

Liquidambar styraciflun

Lirodendron tulipifera

Nyssa syluatica var. biflora

Pinus sp.

red maple

American holly

sweetgum

tulip tree

swamp tupelo

pine

Shrub Seedlings

Baccharis halimifolia

Callicarpa americana

Cephalanihus occidentalis

Ligustrum sp.

Myrica cerifera

Persea borbonia

Rubus sp.

sea-myrtle

French mulberry

button bush

privet

wax myrtle

red bay

blackberry

VINE STRATUM

Berchemia scandens

Gelsemium sempervirens

Lonicera sp.

Mikania scandens

Rhus radicans

Smilax glauca

Smilax laurifolia

rattan vine

yellow jessamine

honeysuckle

climbing hempweed

poison ivy

catbrier

laurel-leaf greenbrier

\section{GROUNDCOVER STRATUM}

Forbs

Aneilema keisak

Boehmeria cylindrica

Hydrocotyle sp.

Hypericum walteri

Ludwigia leptocarpa

Lycopus virginicus

Peltandra virginica

Pluchea camphorata

Tillandsia usneoides

Typha sp.

false nettle water pennywort St. John's wort ludwigia water-hoarhound arrow arum marsh-fleabane Spanish-moss cattail

Grasses

Andropogon virginicus

Carex sp.

Cyperus sp.

Eleocharis sp.

Erianthus giganteus

Juncus effusus

Leersia oryzoides

Panicum sp.

Unknown grass

broomsedge
carex
sedge
spike rush
plume grass
juncus
cut grass
panicum
grass

Ferns

Woodwardia areolata

netted chain fern 
Table 5. Number of tree seedlings, shrub seedlings, and vines by plot in H-Area

\begin{tabular}{|c|c|c|c|c|c|c|c|c|}
\hline $\begin{array}{c}\text { Plot } \\
\#\end{array}$ & $\begin{array}{c}\text { Tree } \\
\text { Seedlings }\end{array}$ & $\begin{array}{c}\text { Shrub } \\
\text { Seedlings }\end{array}$ & Vines & $\begin{array}{l}1 \\
1 \\
1\end{array}$ & $\begin{array}{l}\text { Plot } \\
\#\end{array}$ & $\begin{array}{c}\text { Tree } \\
\text { Seedlings }\end{array}$ & $\begin{array}{c}\text { Shrub } \\
\text { Seedlings }\end{array}$ & Vines \\
\hline 1 & 1 & 3 & 3 & 1 & 29 & & & \\
\hline 2 & & 8 & & 1 & 30 & & & \\
\hline 3 & 4 & 3 & 6 & 1 & 31 & & & \\
\hline 4 & 1 & & 5 & 1 & 32 & & & 1 \\
\hline 5 & & 9 & 5 & 1 & 33 & & & \\
\hline 6 & & 7 & 4 & 1 & 34 & & & \\
\hline 7 & 1 & 3 & 4 & 1 & 35 & & & \\
\hline 8 & 3 & 17 & 7 & 1 & 36 & & & \\
\hline 9 & 1 & 17 & 8 & 1 & 37 & & & \\
\hline 10 & 3 & 10 & 5 & 1 & 38 & & & \\
\hline 11 & & 8 & 1 & 1 & 39 & & & \\
\hline 12 & 1 & 20 & 7 & 1 & 40 & & & \\
\hline 13 & 1 & 6 & 7 & 1 & 41 & & & \\
\hline 14 & 3 & 6 & 3 & 1 & 42 & & & \\
\hline 15 & & 9 & 3 & 1 & 43 & & & 3 \\
\hline 16 & & 1 & & 1 & 44 & & & 6 \\
\hline 17 & & & 1 & 1 & 45 & & & 1 \\
\hline 18 & & & & 1 & 46 & & & 2 \\
\hline 19 & & & 2 & 1 & 47 & & & 2 \\
\hline 20 & & & 1 & 1 & 48 & & & \\
\hline 21 & & & 4 & 1 & 49 & & & \\
\hline 22 & & & & 1 & 50 & & & \\
\hline 23 & & & & 1 & 51 & & & \\
\hline 24 & & & 1 & 1 & 52 & & & \\
\hline 25 & & & & 1 & 53 & & & \\
\hline 26 & & & & 1 & 54 & & & 1 \\
\hline 27 & & & & 1 & 55 & & 1 & 2 \\
\hline 28 & & & & $i$ & 56 & & & \\
\hline
\end{tabular}


Table 6. Groundcover stratum (major components) by plot of H-Area

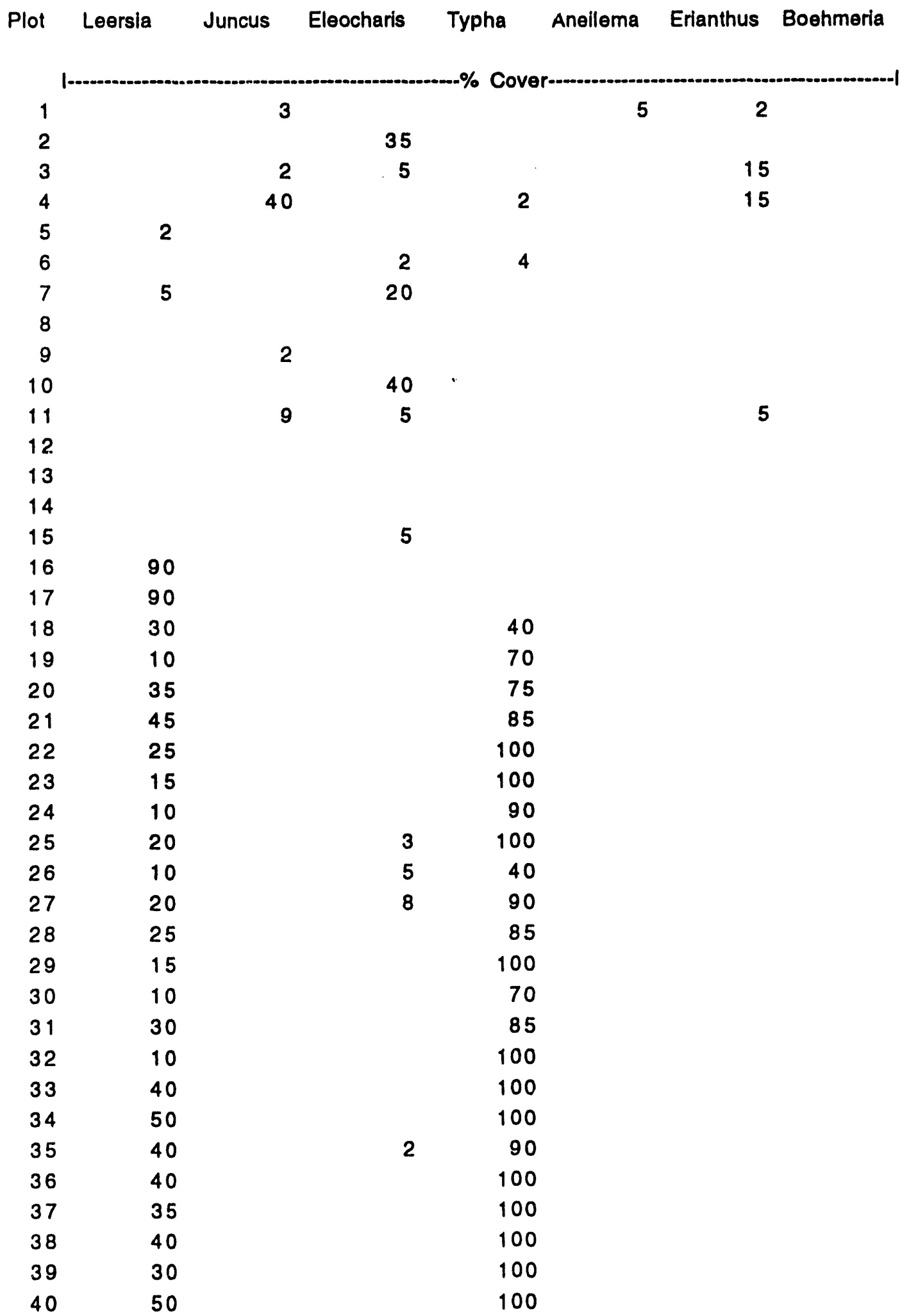




\begin{tabular}{|c|c|c|c|c|c|c|c|}
\hline Plot & Leersia & Juncus & Eleocharis & Typha & Aneilema & Erianthus & Boehmeria \\
\hline 41 & 40 & & & 100 & & & \\
\hline 42 & 40 & & & 80 & & & \\
\hline 43 & 25 & & & 40 & & & \\
\hline 44 & 55 & & & 95 & & & \\
\hline 45 & 75 & & & 80 & & & \\
\hline 46 & 25 & & & 100 & & & \\
\hline 47 & 40 & & & 100 & & & \\
\hline 48 & 40 & & & 90 & 20 & & \\
\hline 49 & 75 & & & 80 & & & 5 \\
\hline 50 & 60 & & & 95 & & & \\
\hline 51 & 60 & & & 80 & & & \\
\hline 52 & 100 & & & 75 & & & \\
\hline 53 & 100 & & & · & & & \\
\hline 54 & 100 & & & & & & \\
\hline 55 & 10 & & & & 100 & & \\
\hline 56 & 7 & & & & 100 & & \\
\hline
\end{tabular}




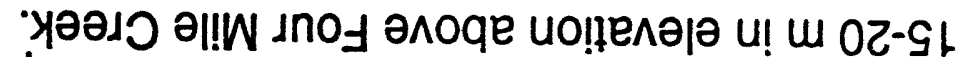

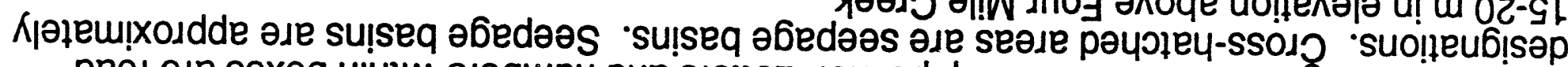

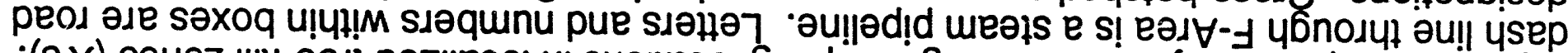

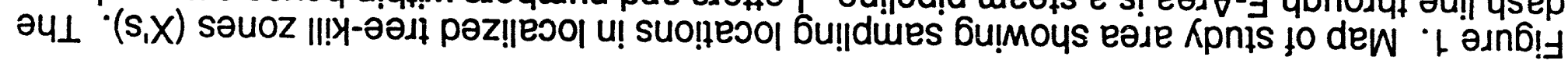

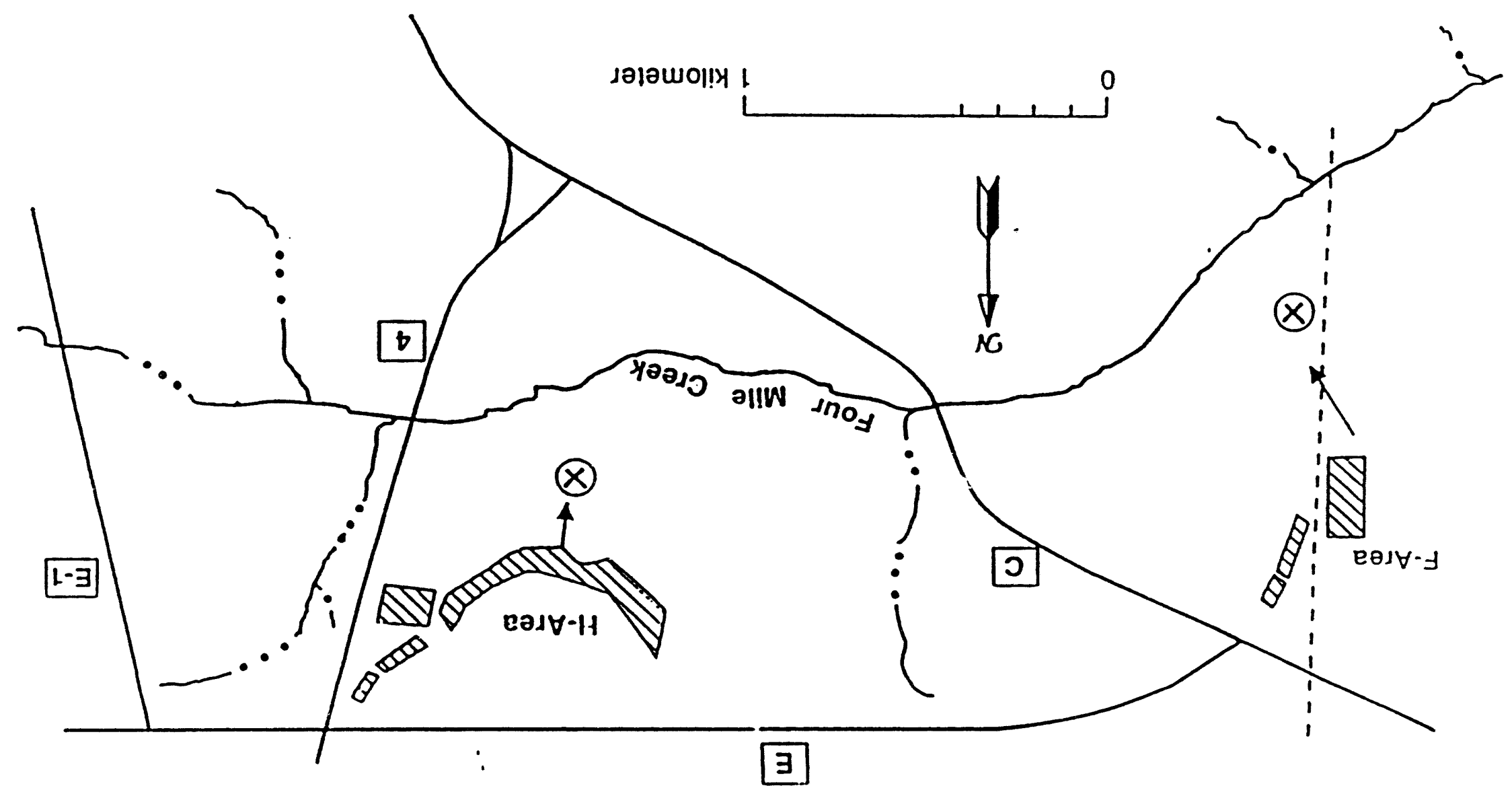




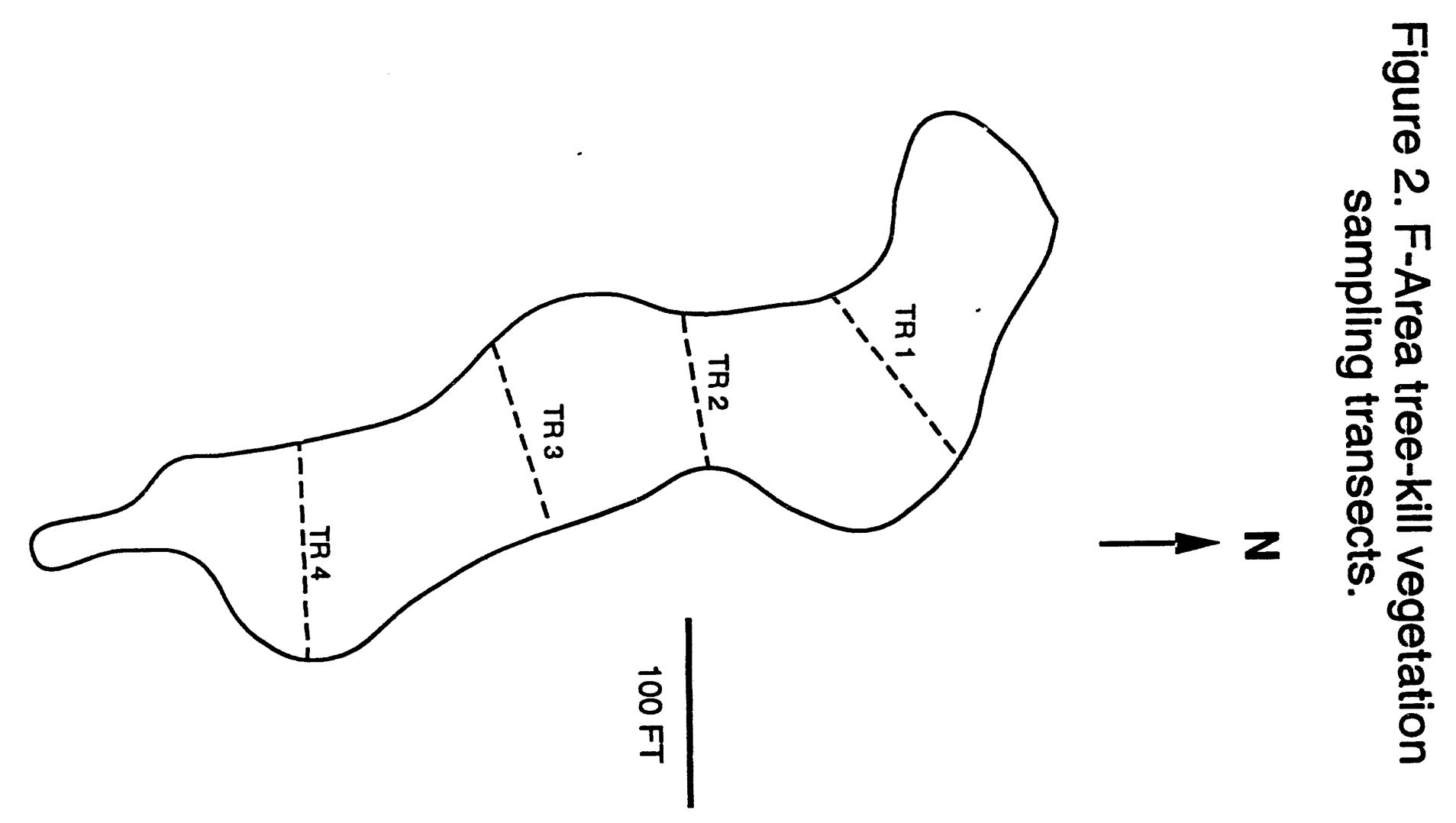


Figure 3. $\mathrm{H}$-Area tree-kill vegetation sampling transect.

Wells HSB 136C,D

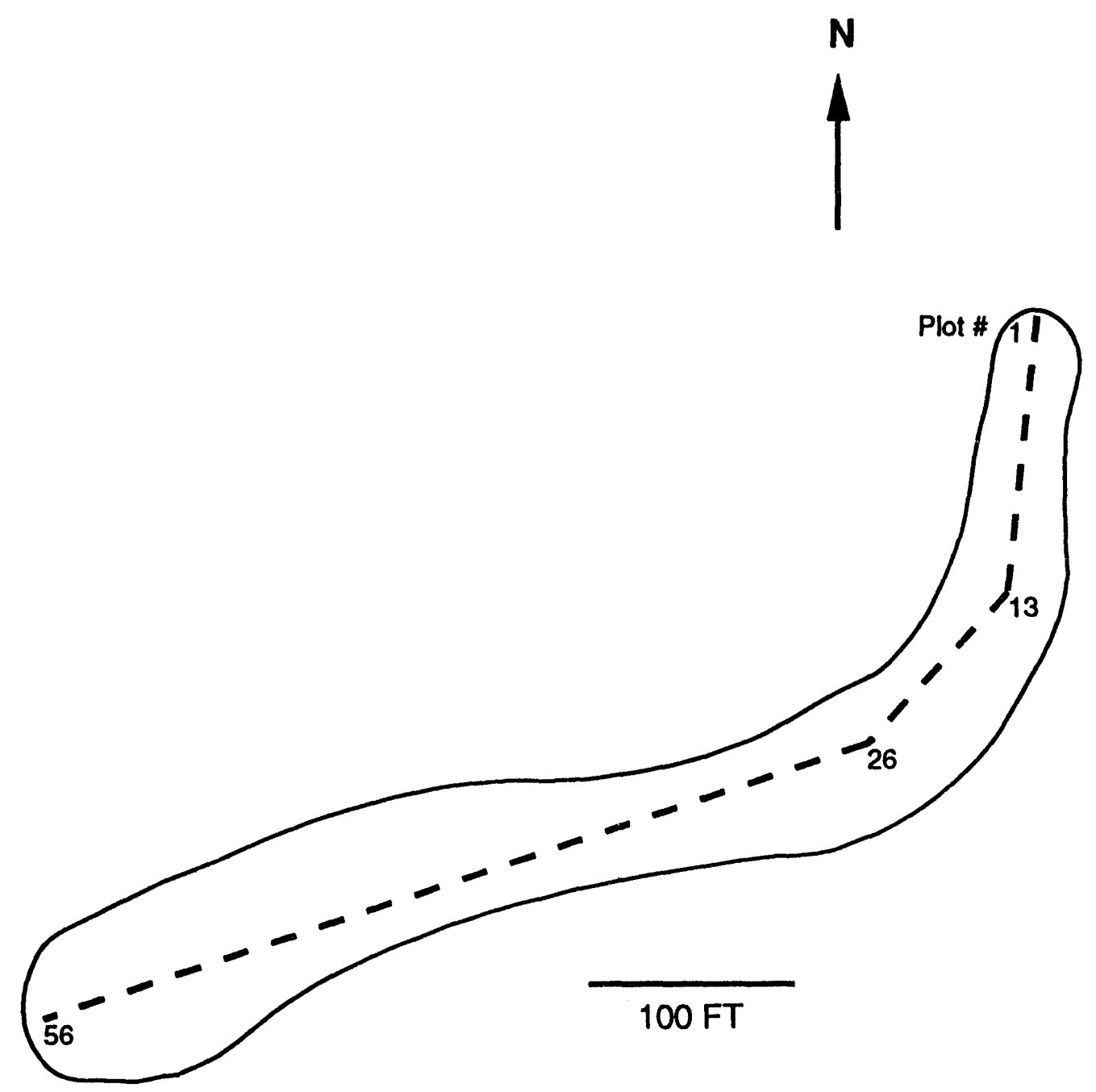




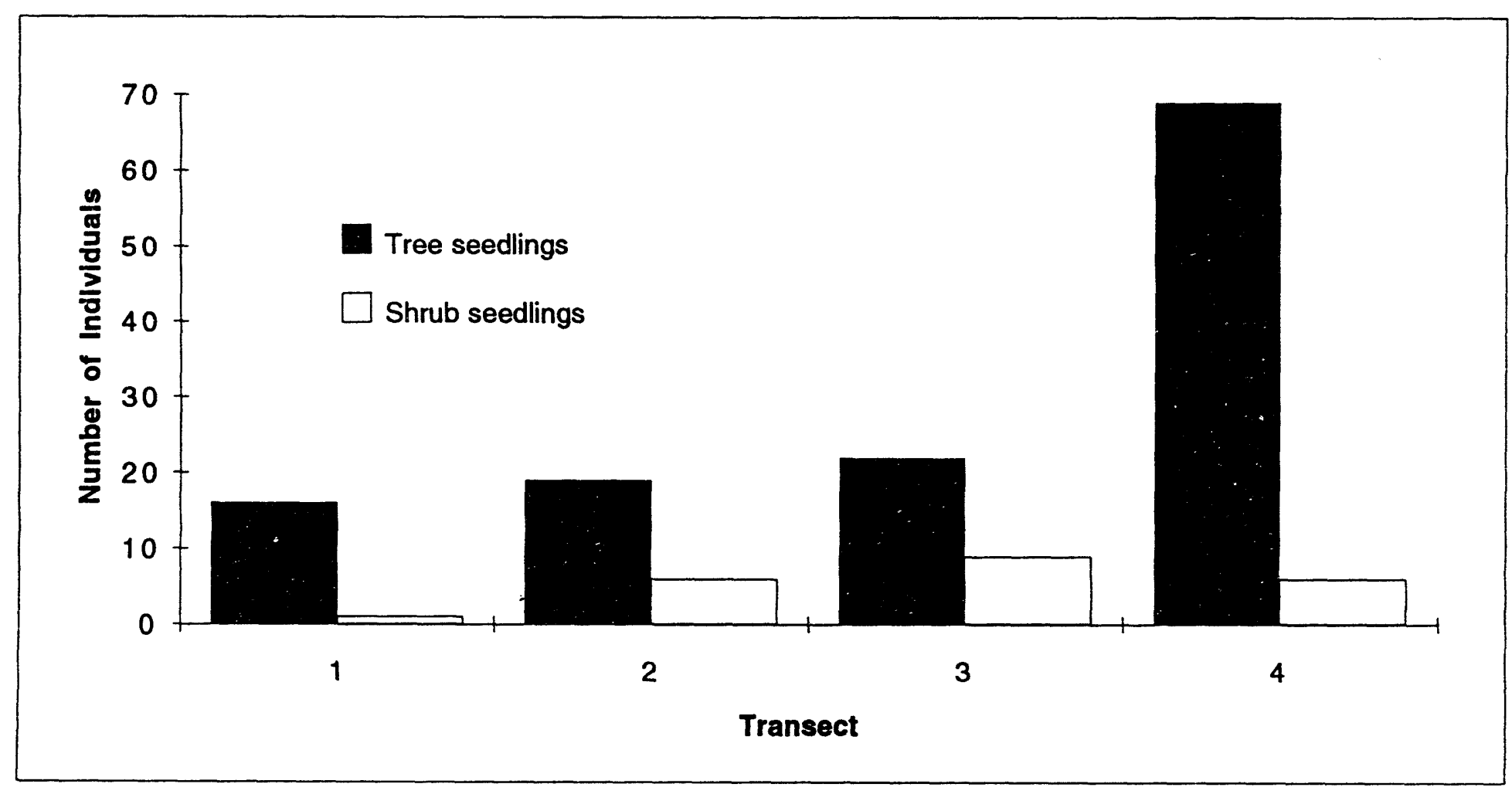

Figure 4. Total number of tree and shrub individuals by transect in F-Area. 


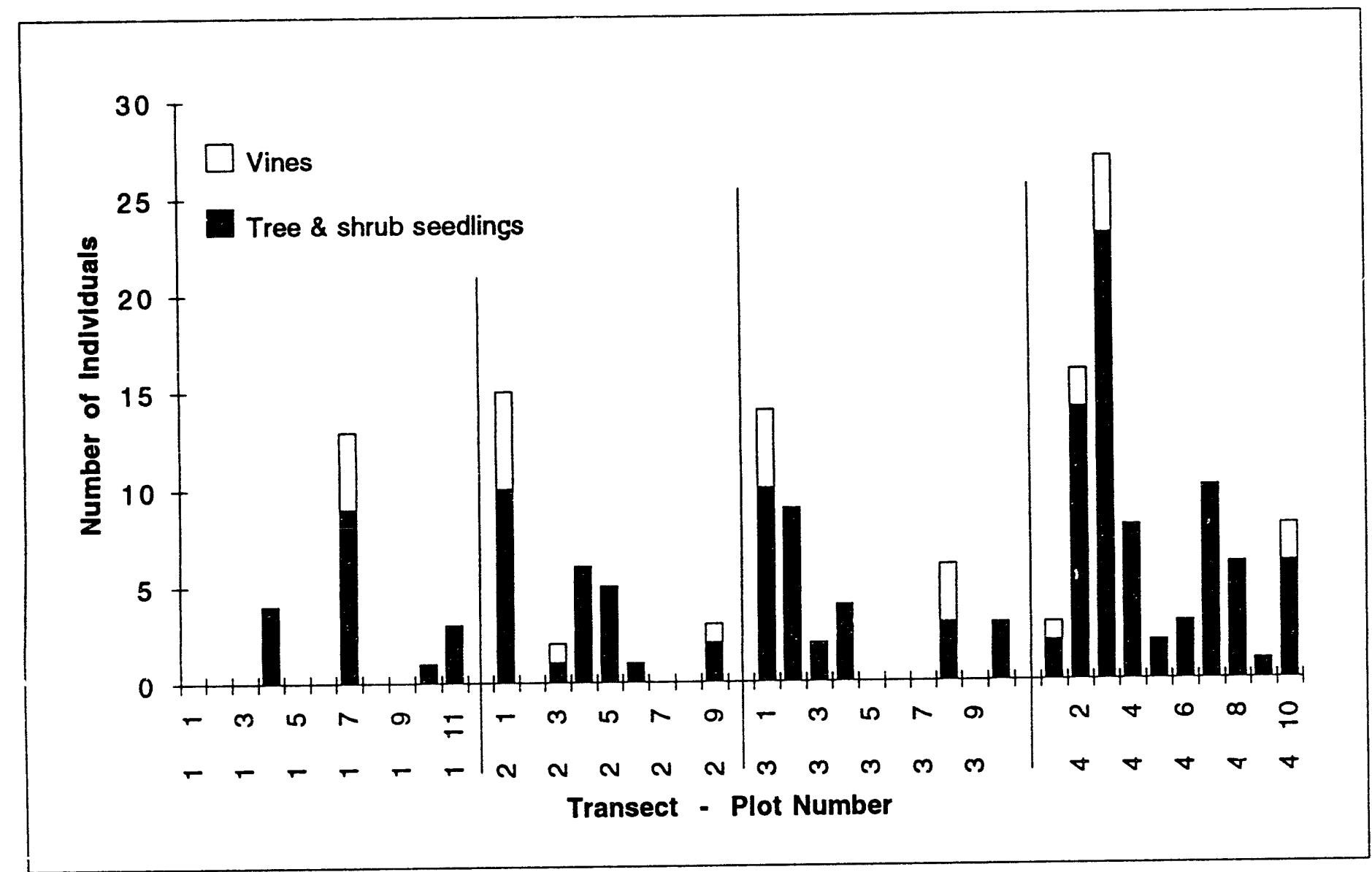

Figure 5. Number of tree and shrub seedlings and vines per plot in F-Area. 


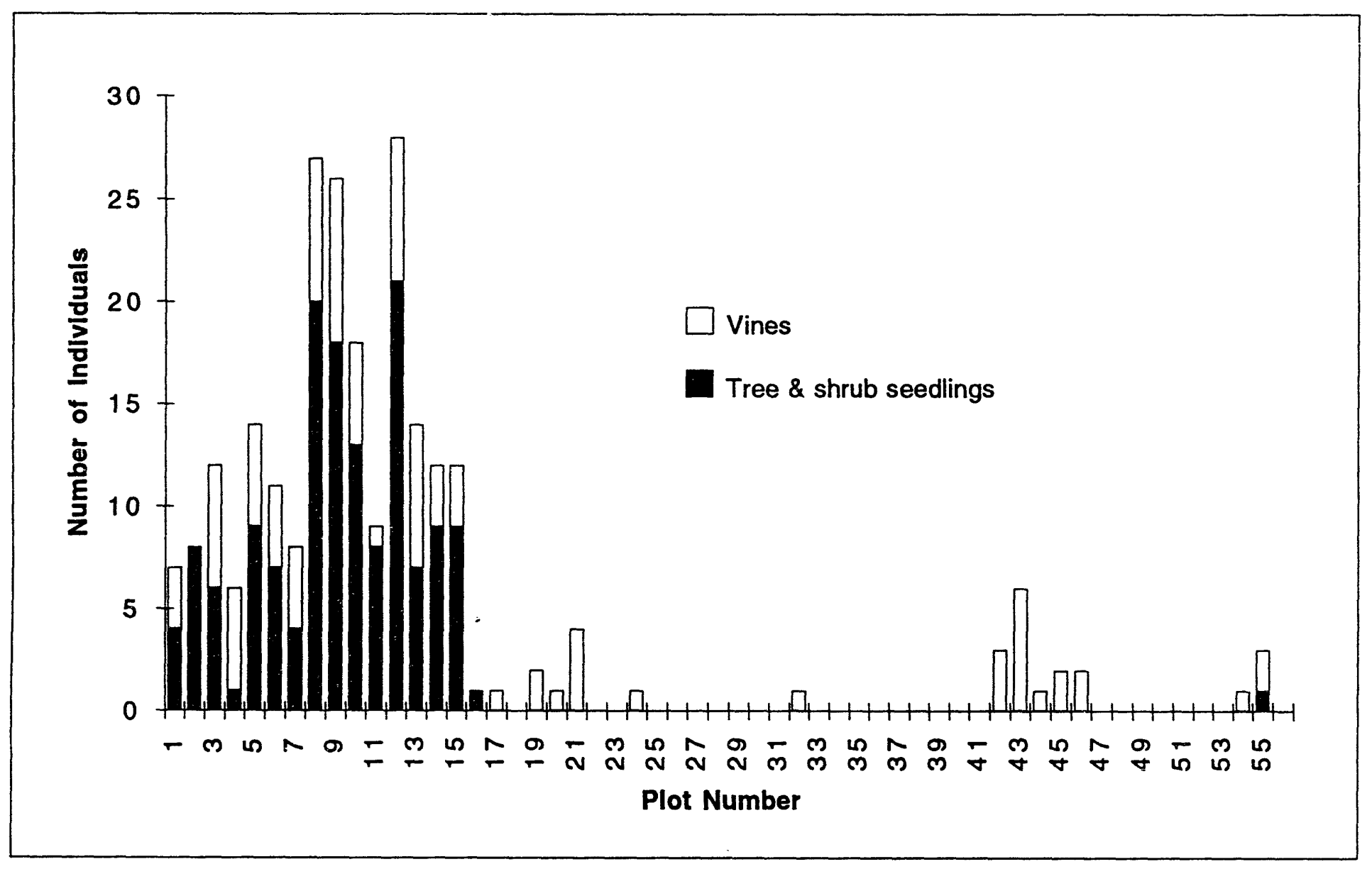

Figure 6. Number of tree and shrub seedlings and vines per plot in H-Area. 


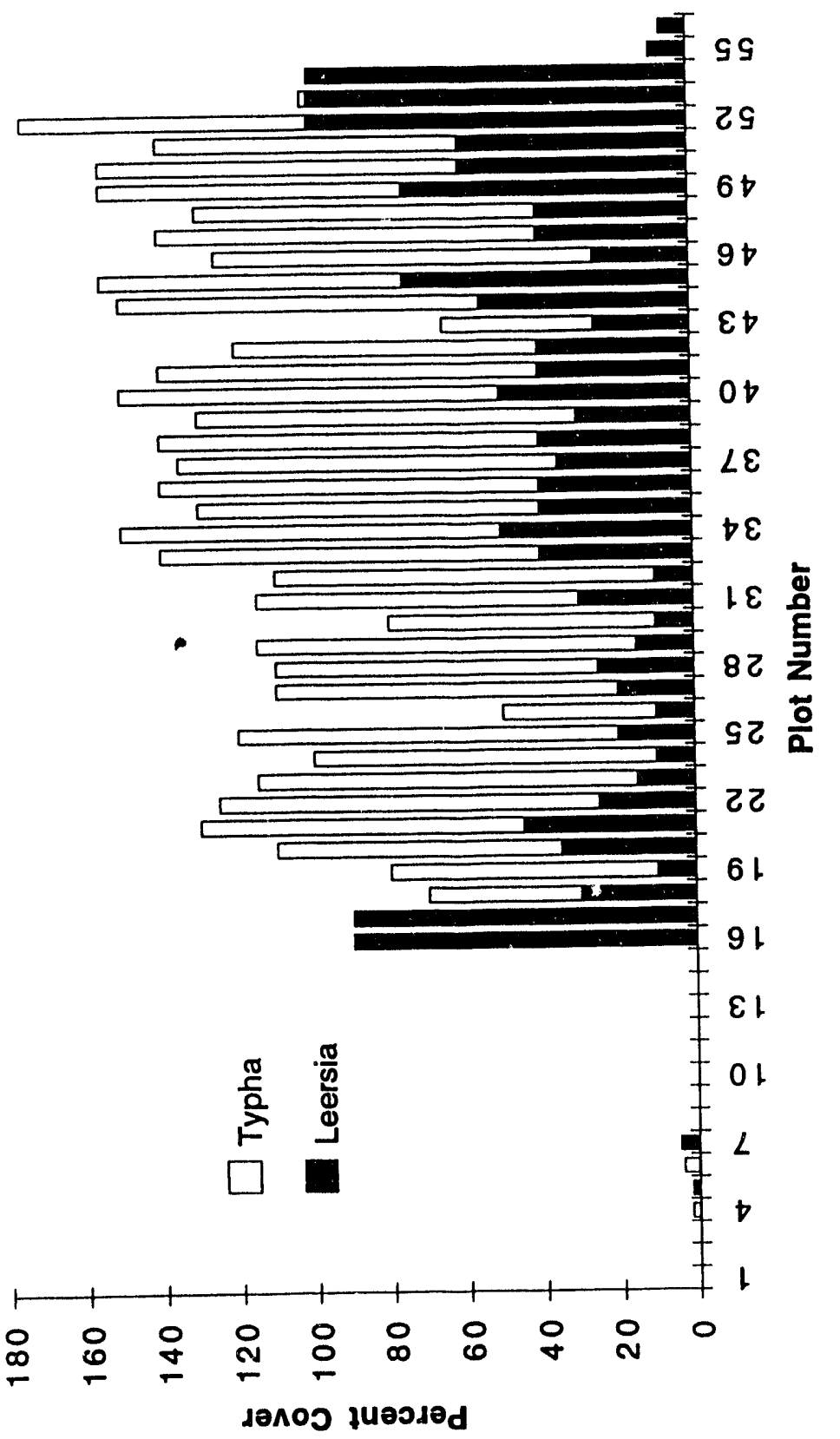

$\frac{10}{0}$

.ㄷ

.

क

త

음

뜨

i

ล

\ั)

N

产

ii 

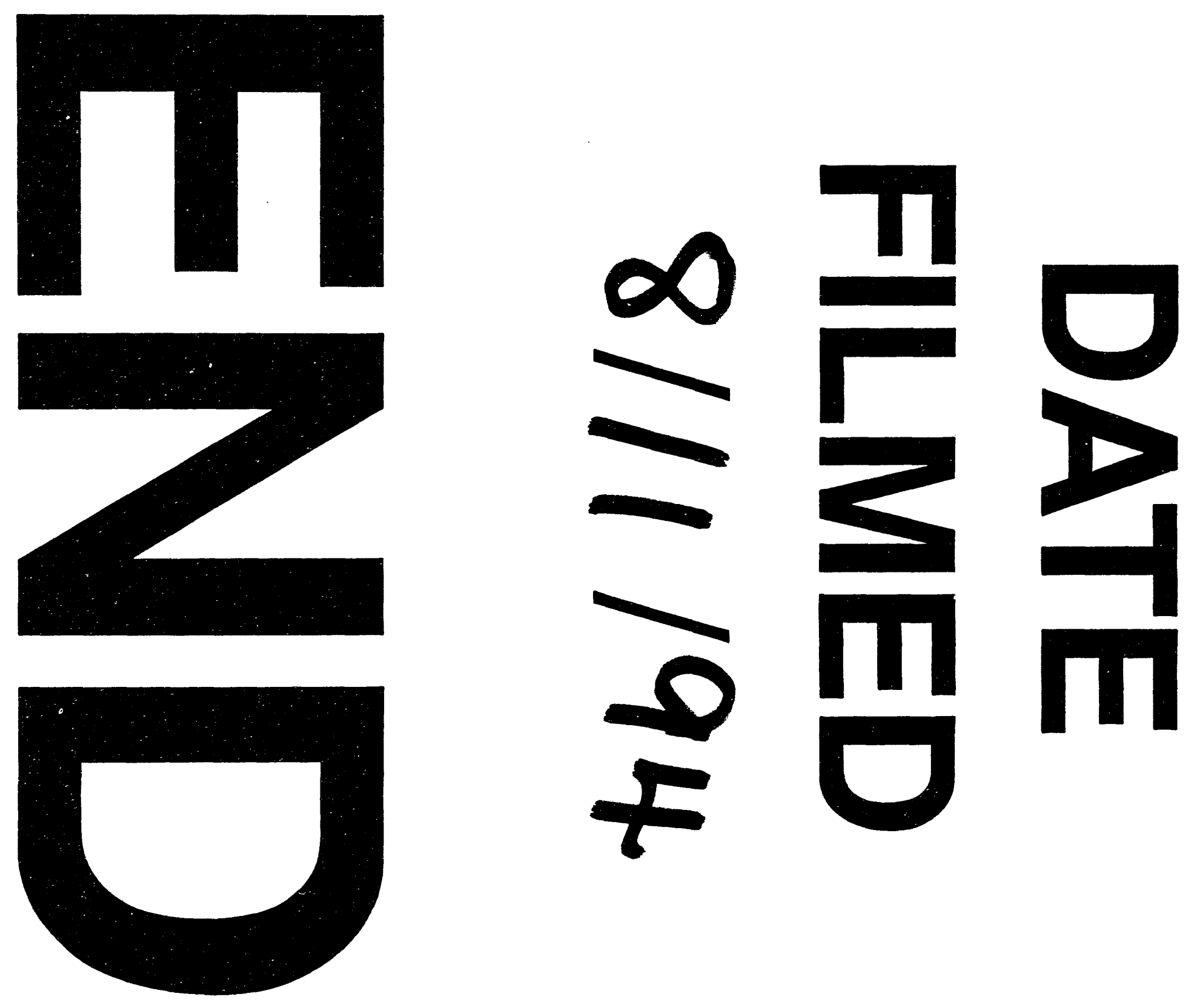
